ISSN 1392-3196 / e-ISSN 2335-8947

Zemdirbyste-Agriculture, vol. 106, No. 1 (2019), p. 87-94

DOI 10.13080/z-a.2019.106.012

\title{
Influence of the storage conditions on the quality of bee pollen
}

\author{
Ofélia ANJOS ${ }^{1,2,3}$, Vanessa PAULA ${ }^{4}$, Teresa DELGADO ${ }^{2}$, Letícia ESTEVINHO \\ ${ }^{1}$ Forest Research Centre, School of Agriculture, University of Lisbon \\ Lisboa, Portugal \\ E-mail: ofelia@ipcb.pt \\ ${ }^{2}$ Polytechnic Institute of Castelo Branco \\ Castelo Branco, Portugal \\ ${ }^{3}$ Plant Biotechnology Center of Beira Interior \\ Castelo Branco, Portugal \\ ${ }^{4}$ School of Agricultural Sciences, Polytechnic Institute of Bragança \\ Bragança, Portugal \\ ${ }^{5}$ Mountain Research Center, Polytechnic Institute of Bragança \\ Bragança, Portugal
}

\begin{abstract}
Bee pollen is a healthful food product with a good nutritional profile and therapeutic properties. However, the storage conditions may affect its composition and characteristics. This study aimed to evaluate the effect of the storage conditions on chemical composition of different monofloral bee pollen samples, namely acidity $(\mathrm{pH})$, water activity, total acidity and the content of fibre, ash, reducing sugars, protein, lipids, total phenols and total flavonoids. Nine bee pollen samples were harvested in three places in the Northeast of Portugal and divided into two aliquots: one was frozen at $-20^{\circ} \mathrm{C}$, while the other was dried at $42^{\circ} \mathrm{C}$, until reaching moisture of $6-8 \%$. Even though differences in the botanical origin are a significant factor explaining the variation between samples, the storage method was also found to be a highly significant factor for several parameters: reducing sugars, lipids, total phenols and total flavonoids. Higher counts were obtained on the frozen bee pollen samples regarding aerobic mesophiles and moulds and yeasts. Even so, for all samples and conservation methods, the values were below those given by the standards.
\end{abstract}

Our study suggests that it is better to consume bee pollen frozen at $-20^{\circ} \mathrm{C}$ in comparison to that dried in an electric oven.

Key words: frozen $v s$ dried, microbiological analysis, physico-chemical analysis.

\section{Introduction}

Several beehive products, produced by Apis mellifera bees, are available nowadays including honey, royal jelly, propolis, bee venom, bee pollen and beeswax. These natural products have been studied over the years and have attracted the interest of both consumers and industries due to their nutritional properties and therapeutic potential (Cornara et al., 2017).

Honey is the main and most widely appreciated honeybee product (Cornara et al., 2017). Bee pollen is another product of the beehive, which over the decades has been studied and consumed by the population, due to its chemical composition (Feás et al., 2012; KomosinskaVassev et al., 2015; Campos et al., 2016). From a nutritional point of view, bee pollen is very rich in protein, fatty-acids, free sugars, carbohydrates, and it contains trace amounts of minerals, phenolic acids, flavonoids and a range of vitamins (Campos et al., 2016; Anjos et al.,
2017; Gonçalves et al., 2017). Interestingly, bee pollen possesses all the essential amino acids in concentrations that are five to seven times higher than those found in most protein-rich products. In addition, bee pollen also possesses antioxidant, antimicrobial, anti-inflammatory, anti-atherosclerotic, antidiabetic and anticancer activities (Campos et al., 2016; Cornara et al., 2017).

Bee pollen is one of the main sources of the food to the honeybees, providing a wide range of nutrients. This product is a result of interaction of flower pollen with nectar (and/or honey) and salivary substances carried out by the worker bees (Campos et al., 2008). Bee pollen may be consumed fresh, but it is more commonly used after drying at $40-50^{\circ} \mathrm{C}$, which reduces microbial spoilage and assures long-term stability and safety. Despite its advantages, drying may potentially affect bee pollen organoleptic features and polyphenols and 
flavonoids content (Mauriello et al., 2017). Alternatively, freezing may be used to preserve the sensorial and nutritional characteristics of this beehive product.

Studies of dried and stored bee pollen have been performed to evaluate its properties, including chemical composition and the botanical origin (Barth et al., 2010), presence of vitamin B complex, physico-chemical composition (Arruda et al., 2013), nutritional content (Human, Nicolson, 2006) and organoleptic quality (Siuda et al., 2012). However, few studies have been performed regarding bee pollen conservation procedures. The objective of this work was to evaluate the effect of the storage method (frozen $v s$ dried) on the nutritional composition and microbiological quality of bee pollen.

\section{Materials and methods}

Samples collection. Bee pollen was collected in three regions from the Northeast of Portugal: Angueira, Vimioso and Mogadouro, from beehives equipped with bottom-fitted pollen traps. A first screening of microbiological parameters was performed for quality and safety assurance. All values obtained were within the hygienic standards recommended by Campos et al. (2008). The botanical origin of the bee pollen samples was determined as previously described by Feás et al. (2012). Briefly, $2 \mathrm{~g}$ of each sample were separated by colour and then analysed on an optical microscope with total $(400 \times$ and $1000 \times)$ magnification. The reference collection of the Agricultural College of Bragança and different pollen morphology guides were used for pollen grain recognition. After the separation, nine different subsamples of pollen by colour were obtained. These subsamples were divided into two aliquots: one was frozen at $-20^{\circ} \mathrm{C}$, while the other was dried at $40^{\circ} \mathrm{C}$ in a forced convection oven ESA 1368 (Sercon Ltd.), until reaching moisture content of 6-8\%. Further analysis was performed using 18 subsamples, 9 frozen and 9 dried. The samples were collected in May of 2016, and the analyses were performed after 6 months of storage period.

Physico-chemical analysis. In the frozen and dried bee pollen samples several analytical parameters were determined, including moisture content, acidity $(\mathrm{pH})$, total acidity, ash, reducing sugars, lipids, protein, and fibre, total polyphenol and total flavonoid contents. Moisture content and fibre percentage of the pollen samples were determined according to the Association of Official Analytical Chemists Procedures (AOAC, 1995). Acidity $(\mathrm{pH})$ was measured in the aqueous mixture, prepared by mixing of $10 \mathrm{~g}$ of pollen in 75 $\mathrm{mL}$ of distilled water, and using a digital $\mathrm{pH}$ meter pH 526 Multical (WTW, Germany). Ash content was determined gravimetrically after ignition at $600 \pm$ $15^{\circ} \mathrm{C}$. Determination of reducing sugar content was performed as follows: $60 \mathrm{mg}$ of each pollen sample was dissolved in a sulphuric acid solution $(10 \mathrm{~mL}, 1.5 \mathrm{M})$, the solutions were heated in a water bath $\left(100^{\circ} \mathrm{C}\right)$ for $20 \mathrm{~min}$, neutralized with $12 \mathrm{~mL}$ sodium hydroxide $(\mathrm{NaOH})(10 \%$, $\mathrm{w} / \mathrm{v}$ ), filtered and diluted to total volume of $60 \mathrm{ml}$ with distilled water. The quantification of reducing sugars was performed spectrophotometrically at $540 \mathrm{~nm}$ using a UV-VIS spectrophotometer (Unicam Helios, UK). Determination of the total lipid content was performed as following: $2 \mathrm{~g}$ of pollen were macerated with anhydrous sodium sulphate and extracted with n-hexane for about 4 $\mathrm{h}$ in the Soxhlet apparatus (Behrotest, Germany). Protein content was determined from the total nitrogen using the conversion factor $6.25(\mathrm{~N} \times 6.25)$, using the Kjeldahl method with 230-Hjeltec analyzer (Foss Tecator, Sweden). The total phenolic content of the extracts was determined using the Folin-Ciocalteu method as described by Moreira et al. (2008). For determination of total flavonoid content, the aluminium chloride method was used. Total flavonoid content was expressed as $\mathrm{mg}$ of catechin equivalent (CAE) per $\mathrm{g}$ of bee pollen.

Microbiological analysis. Mesophilic aerobic bacteria were determined as recommended by the standard NP-3788 (Food microbiology - general rules for count of microorganism at $30^{\circ} \mathrm{C}$ ) using plate count agar (PCA) (HiMedia, India) incubated at $30^{\circ} \mathrm{C}$ for $24 \mathrm{~h}$. Moulds and yeasts were quantified in potato dextrose agar (PDA) acidified with tartaric acid (both purchased from HiMedia, India) and incubated at $25^{\circ} \mathrm{C}$ for $48 \mathrm{~h}$, following the recommendations of ISO 21572-2:2008 (Microbiology of food and animal feeding stuffs - Horizontal method for the enumeration of yeasts and moulds. Part 2: Colony count technique in products with water activity less than or equal to 0.95). The enumeration of total coliforms and Escherichia coli was performed using SimPlate of BioControl kit (AOAC, 2000). The presence of sulphitereducing clostridia spores was evaluated according to the ISO 15213:2003 (Microbiology of food and animal feeding stuffs - Horizontal method for the enumeration of sulfite-reducing bacteria growing under anaerobic conditions). Determination of coagulase-positive Staphylococcus was performed as reported in the standard NP-4400-1 (Food microbiology - General rules for count of coagulase-positive staphylococci (Staphylococcus aureus and other species). Part 1: Technique including confirmation of colonies). Enumeration of Bacillus cereus was done using $B$. cereus selective agar base supplemented with $100.000 \mathrm{IU} \mathrm{L}^{-1}$ of polymixin $\mathrm{B}$ and $50 \mathrm{ml} \mathrm{L}^{-1}$ of egg yolk emulsion (all purchased at Oxoid Limited, UK). The presence of Salmonella spp. was assessed using the 1-2 Test kit (BioControl) (AOAC, 2000) and the presence of Listeria monocytogenes was ascertained as recommended by AOAC (2002).

Statistical analysis. A two-way analysis of variance $(A N O V A)$ was performed with two factors: species (9 levels: 9 different species or group species) and the storage method (2 levels: frozen (F) and dried (D)) as fixed factors. Comparison of means was performed with a Scheffee post-hoc test with $95 \%$ confidence intervals. In the results the same letter represents that the values obtained do not differ statistically $(p>0.05)$. The results were also subjected to a multivariate analysis (principal component analysis) to study the association between variables and cases. The experimental data were analysed using software Statistica, version 7.0 (StatSoft Inc., USA).

\section{Results and discussion}

The samples were coded according to the predominant botanical family of pollen grains (Table 1).

Usually bee pollen is commercialized as a mixture because it is difficult to obtain a monofloral bee pollen product. Nevertheless, it is important to characterize the individual botanical types regarding their particular nutritional and chemical composition in order to help the beekeepers to select and enrich the areas surrounding the apiaries with the types of plants that allow them to improve the properties and quality of the final product. 
Table 1. Codes and spectra of different bee pollen samples used in the study

\begin{tabular}{|c|c|}
\hline $\begin{array}{l}\text { Sample codification and percentage } \\
\text { of predominant pollen }\end{array}$ & Minor pollen \\
\hline $\begin{array}{l}\mathrm{Ru} \\
\text { Rubus spp. }(89.6 \pm 2.8)\end{array}$ & $\begin{array}{l}\text { Castanea sativa: } 2.5 \pm 0.5, \text { Cytisus } \text { spp.: }<1, \text { Quercus spp.: }<1 \\
\text { Echium spp.: } 2.2 \pm 0.8, \text { Leontondon spp.: } 2.0 \pm 0.8 \text {, Erica } \text { spp.: } 2.5 \pm 0.8\end{array}$ \\
\hline $\begin{array}{l}\mathrm{Ca} \\
\text { Castanea sativa }(91.0 \pm 3.2)\end{array}$ & $\begin{array}{l}\text { Cytisus spp.: } 2.0 \pm 0.7 \text {, Quercus spp.: } 2.0 \pm 0.8 \text {, Prunus spp.: } 2.3 \pm 1.2 \text {, } \\
\text { Eucalyptus spp.: } 2.7 \pm 1.1\end{array}$ \\
\hline $\begin{array}{l}\mathrm{Ci} \\
\text { Cistus spp. }(87.7 \pm 2.4) \\
\end{array}$ & $\begin{array}{l}\text { Rubus spp.: } 2.0 \pm 0.6, \text { Castanea sativa: } 2.2 \pm 0.7, \text { Echium spp.: } 2.6 \pm 0.6 \text {, } \\
\text { Leontondon spp.: } 1.9 \pm 0.5 \text {, Eucalyptus } \text { spp.: } 3.0 \pm 0.3 \text {, Erica } \text { spp.: }<1\end{array}$ \\
\hline $\begin{array}{l}\text { Le } \\
\text { Leontondon spp. }(85.6 \pm 4.3)\end{array}$ & $\begin{array}{l}\text { Castanea sativa: } 2.5 \pm 1.7 \text {, Cytisus spp.: } 1.6 \pm 1.6 \text {, Quercus } \text { spp.: }<1 \text {, } \\
\text { Echium spp.: } 1.5 \pm 0.6 \text {, Prunus spp.: } 1.1 \pm 0.6 \text {, Eucalyptus } \text { spp.: }<1 \\
\text { Erica } \text { spp.: } 1.9 \pm 0.5 \text {, Cistus } \text { spp.: } 2.5 \pm 1.0, \text { Trifolium spp.: } 2.2 \pm 1.6\end{array}$ \\
\hline $\begin{array}{l}\text { Cy } \\
\text { Cytisus spp. }(90.0 \pm 3.1)\end{array}$ & $\begin{array}{l}\text { Rubus spp.: } 1.1 \pm 0.6, \text { Castanea sativa: } 2.0 \pm 0.7 \text {, Echium } \text { spp.: } 2.7 \pm 0.9 \text {, } \\
\text { Leontondon spp.: } 1.2 \pm 0.5 \text {, Erica } \text { spp.: } 1.5 \pm 1.0 \text {, Cistus } \text { spp.: } 1.5 \pm 0.4\end{array}$ \\
\hline $\begin{array}{l}\text { Ec } \\
\text { Echium spp. }(89.8 \pm 2.0)\end{array}$ & Castanea sativa: $2.3 \pm 0.9$, Quercus spp.: $2.5 \pm 0.5$, Cistus spp.: $5.3 \pm 1.1$ \\
\hline $\begin{array}{l}\mathrm{Ca}+\mathrm{Ec} \\
\text { Castanea sativa }(37.2 \pm 2.5)+ \\
\text { Echium spp. }(23.4 \pm 3.4) \\
\end{array}$ & $\begin{array}{l}\text { Rubus spp.: } 3.6 \pm 1.0, \text { Leontondon spp.: } 2.6 \pm 1.7 \text {, Erica } \text { spp.: } 8.1 \pm 1.0 \text {, } \\
\text { Cistus spp.: } 15.1 \pm 2.2\end{array}$ \\
\hline $\begin{array}{l}\text { Eu }+ \text { Er } \\
\text { Eucalyptus spp. }(27.4 \pm 1.8)+ \\
\text { Erica spp. }(27.6 \pm 2.4)\end{array}$ & $\begin{array}{l}\text { Quercus spp.: } 12.3 \pm 0.8, \text { Echium spp.: } 7.7 \pm 2.2 \text {, Prunus spp.: } 11.5 \pm 2.5 \text {, } \\
\text { Trifolium spp.: } 13.5 \pm 1.1\end{array}$ \\
\hline $\begin{array}{l}\text { Er } \\
\text { Erica } \text { spp. }(89.9 \pm 4.2)\end{array}$ & $\begin{array}{l}\text { Cytisus spp.: } 3.2 \pm 1.9, \text { Prunus spp.: }<1, \text { Leontondon spp.: } 1.5 \pm 0.6 \text {, } \\
\text { Cistus spp.: } 2.0 \pm 0.7 \text {, Trifolium spp.: } 3.0 \pm 1.2\end{array}$ \\
\hline
\end{tabular}

The average values of the chemical and nutritional composition (expressed on a dry weight basis) obtained for the 9 bee pollen samples are represented in Tables 2 and 3. The shelf lifetime of bee pollen is influenced by various parameters including the water activity. The water activity reflects the amount of water available for spoilage microorganisms (bacteria, fungi and yeasts) thus plays a key role. Yeasts and moulds generally grow when water activity value is above 0.61 , while for growth of bacteria the water activity value should be higher than 0.91 . Therefore, water acidity values are an important parameter to consider when studying the shelf life of bee pollen (Sagona et al., 2017). The water activity values obtained in the present study ranged between 0.26 and 0.34 for dried bee pollen and from 0.58 to 0.72 for frozen bee pollen. Similar results were reported by different authors who analysed dried bee pollen from Portugal
(Feás et al., 2012), Brazil (Carpes et al., 2009) and Spain (Bonvehi, Jordà, 1997). The variations between water activity in the different samples are related mainly to the storage process (in frozen samples the water content is higher), but some differences are also influenced by the botanical origin of bee pollen (Tables 2 and 3 ).

All analysed bee pollen samples were acidic, with a $\mathrm{pH}$ ranging between 4.3 and 5.4. The different botanical origin of the samples was the main factor for such $\mathrm{pH}$ differences, while the results obtained for the influence of the storage method were not significant $(p<0.05)$ (Table 4). The $\mathrm{pH}$ values reported in this study are similar to those reported by Feás et al. (2012) and Anjos et al. (2017). The low acidity $(\mathrm{pH})$ and water activity values in the dried bee pollen inhibit the growth of microorganisms decreasing the possible problems with texture and stability and increasing the shelf life of the product.

Table 2. Physico-chemical values of organic bee pollen samples dried and frozen (mean \pm standard deviation)

\begin{tabular}{cccccc}
\hline Code & $\begin{array}{c}\text { Storage } \\
\text { method }\end{array}$ & Water activity & Acidity $(\mathrm{pH})$ & $\begin{array}{c}\text { Total acidity } \\
\text { meq NaOH kg-1 }\end{array}$ & $\begin{array}{c}\text { Ash } \\
\%\end{array}$ \\
\hline \multirow{2}{*}{$\mathrm{Ru}$} & $\mathrm{F}$ & $0.59 \pm 0.01 \mathrm{~b}$ & $5.43 \pm 0.40 \mathrm{~b}$ & $13.53 \pm 0.21 \mathrm{a}$ & $\begin{array}{c}1.87 \pm 0.12 \mathrm{a} \\
\end{array}$ \\
& $\mathrm{D}$ & $0.31 \pm 0.04 \mathrm{a}$ & $4.68 \pm 0.20 \mathrm{a}$ & $14.62 \pm 0.85 \mathrm{~b}$ & $1.98 \pm 0.08 \mathrm{a}$ \\
\hline \multirow{2}{*}{$\mathrm{Ca}$} & $\mathrm{F}$ & $0.67 \pm 0.07 \mathrm{~b}$ & $5.21 \pm 0.51 \mathrm{a}$ & $19.90 \pm 1.85 \mathrm{a}$ & $2.74 \pm 0.38 \mathrm{~b}$ \\
& $\mathrm{D}$ & $0.34 \pm 0.02 \mathrm{a}$ & $5.28 \pm 0.09 \mathrm{a}$ & $18.89 \pm 0.56 \mathrm{a}$ & $2.18 \pm 0.30 \mathrm{a}$ \\
\hline \multirow{2}{*}{$\mathrm{Ci}$} & $\mathrm{F}$ & $0.68 \pm 0.07 \mathrm{~b}$ & $4.70 \pm 0.47 \mathrm{a}$ & $19.83 \pm 1.93 \mathrm{a}$ & $1.92 \pm 0.19 \mathrm{a}$ \\
& $\mathrm{D}$ & $0.28 \pm 0.01 \mathrm{a}$ & $4.52 \pm 0.53 \mathrm{a}$ & $19.57 \pm 1.32 \mathrm{a}$ & $2.59 \pm 0.02 \mathrm{~b}$ \\
\hline \multirow{2}{*}{$\mathrm{Le}$} & $\mathrm{F}$ & $0.67 \pm 0.08 \mathrm{~b}$ & $4.33 \pm 0.24 \mathrm{a}$ & $21.20 \pm 1.02 \mathrm{a}$ & $1.77 \pm 0.28 \mathrm{a}$ \\
& $\mathrm{D}$ & $0.29 \pm 0.05 \mathrm{a}$ & $4.67 \pm 0.41 \mathrm{a}$ & $20.91 \pm 1.13 \mathrm{a}$ & $1.91 \pm 0.19 \mathrm{a}$ \\
\hline \multirow{2}{*}{$\mathrm{Cy}$} & $\mathrm{F}$ & $0.57 \pm 0.03 \mathrm{~b}$ & $4.56 \pm 0.51 \mathrm{a}$ & $17.50 \pm 0.66 \mathrm{a}$ & $1.81 \pm 0.18 \mathrm{a}$ \\
& $\mathrm{D}$ & $0.26 \pm 0.03 \mathrm{a}$ & $4.66 \pm 0.41 \mathrm{a}$ & $16.69 \pm 1.14 \mathrm{a}$ & $1.77 \pm 0.09 \mathrm{a}$ \\
\hline \multirow{2}{*}{$\mathrm{Ec}$} & $\mathrm{F}$ & $0.72 \pm 0.10 \mathrm{~b}$ & $4.70 \pm 0.50 \mathrm{a}$ & $17.08 \pm 0.88 \mathrm{a}$ & $1.95 \pm 0.07 \mathrm{a}$ \\
& $\mathrm{D}$ & $0.31 \pm 0.03 \mathrm{a}$ & $5.08 \pm 0.17 \mathrm{a}$ & $17.89 \pm 1.69 \mathrm{a}$ & $1.96 \pm 0.04 \mathrm{a}$ \\
\hline \multirow{2}{*}{$\mathrm{Ca}+\mathrm{Ci}$} & $\mathrm{F}$ & $0.64 \pm 0.09 \mathrm{~b}$ & $4.44 \pm 0.10 \mathrm{a}$ & $18.83 \pm 0.77 \mathrm{a}$ & $1.85 \pm 0.15 \mathrm{a}$ \\
& $\mathrm{D}$ & $0.33 \pm 0.05 \mathrm{a}$ & $4.81 \pm 0.37 \mathrm{~b}$ & $19.69 \pm 1.56 \mathrm{a}$ & $1.92 \pm 0.15 \mathrm{a}$ \\
\hline \multirow{2}{*}{$\mathrm{Eu}+\mathrm{Er}$} & $\mathrm{F}$ & $0.58 \pm 0.04 \mathrm{~b}$ & $4.67 \pm 0.41 \mathrm{a}$ & $18.14 \pm 1.21 \mathrm{a}$ & $2.00 \pm 0.24 \mathrm{a}$ \\
& $\mathrm{D}$ & $0.27 \pm 0.04 \mathrm{a}$ & $4.52 \pm 0.53 \mathrm{a}$ & $19.33 \pm 1.53 \mathrm{a}$ & $1.98 \pm 0.06 \mathrm{a}$ \\
\hline \multirow{2}{*}{$\mathrm{Er}$} & $\mathrm{F}$ & $0.6 \pm 0.05 \mathrm{~b}$ & $4.54 \pm 0.11 \mathrm{a}$ & $19.85 \pm 1.23 \mathrm{a}$ & $1.87 \pm 0.12 \mathrm{a}$ \\
& $\mathrm{D}$ & $0.29 \pm 0.03 \mathrm{a}$ & $4.66 \pm 0.41 \mathrm{a}$ & $20.73 \pm 1.15 \mathrm{a}$ & $2.13 \pm 0.19 \mathrm{~b}$ \\
\hline
\end{tabular}

Note. Sample codification explained in Table 1; F - frozen, D - dried. 
Table 3. Nutritional values of organic bee pollen samples dried and frozen (mean \pm standard deviation)

\begin{tabular}{cccccccc}
\hline \multirow{2}{*}{ Code } & $\begin{array}{c}\text { Storage } \\
\text { method }\end{array}$ & $\begin{array}{c}\text { Reducing sugar } \\
\%\end{array}$ & $\begin{array}{c}\text { Protein } \\
\%\end{array}$ & $\begin{array}{c}\text { Lipids } \\
\%\end{array}$ & $\begin{array}{c}\text { Fibre } \\
\%\end{array}$ & $\begin{array}{c}\text { TPC } \\
\text { mg GAE g }\end{array}$ & $\begin{array}{c}\text { TFC } \\
\text { m CAE g }^{-1}\end{array}$ \\
\hline \multirow{2}{*}{$\mathrm{Ru}$} & $\mathrm{F}$ & $44.02 \pm 0.48 \mathrm{a}$ & $17.52 \pm 0.41 \mathrm{a}$ & $3.74 \pm 0.54 \mathrm{a}$ & $2.75 \pm 0.42 \mathrm{a}$ & $21.26 \pm 2.22$ & $4.85 \pm 0.53$ \\
& $\mathrm{D}$ & $53.55 \pm 0.60 \mathrm{~b}$ & $18.94 \pm 1.94 \mathrm{a}$ & $4.39 \pm 0.07 \mathrm{~b}$ & $2.83 \pm 0.23 \mathrm{a}$ & $15.28 \pm 2.46$ & $3.93 \pm 0.83$ \\
\hline \multirow{2}{*}{$\mathrm{Ca}$} & $\mathrm{F}$ & $42.73 \pm 2.71 \mathrm{~b}$ & $20.76 \pm 2.54 \mathrm{~b}$ & $3.56 \pm 0.78 \mathrm{a}$ & $2.06 \pm 0.18 \mathrm{a}$ & $35.30 \pm 0.30$ & $6.58 \pm 0.29$ \\
& $\mathrm{D}$ & $36.20 \pm 1.71 \mathrm{a}$ & $18.00 \pm 0.29 \mathrm{a}$ & $4.55 \pm 0.29 \mathrm{~b}$ & $2.12 \pm 0.23 \mathrm{a}$ & $35.05 \pm 0.05$ & $6.99 \pm 0.33$ \\
\hline \multirow{2}{*}{$\mathrm{Ci}$} & $\mathrm{F}$ & $46.57 \pm 2.42 \mathrm{~b}$ & $21.11 \pm 2.35 \mathrm{a}$ & $4.00 \pm 0.31 \mathrm{a}$ & $1.23 \pm 0.23 \mathrm{a}$ & $27.62 \pm 2.10$ & $2.51 \pm 0.28$ \\
& $\mathrm{D}$ & $42.46 \pm 0.32 \mathrm{a}$ & $24.53 \pm 0.36 \mathrm{~b}$ & $5.15 \pm 0.45 \mathrm{~b}$ & $1.53 \pm 0.10 \mathrm{~b}$ & $17.64 \pm 1.57$ & $2.96 \pm 0.32$ \\
\hline \multirow{2}{*}{$\mathrm{Le}$} & $\mathrm{F}$ & $46.55 \pm 3.59 \mathrm{a}$ & $20.20 \pm 1.63 \mathrm{a}$ & $4.94 \pm 0.33 \mathrm{a}$ & $1.58 \pm 0.08 \mathrm{a}$ & $30.28 \pm 2.06$ & $2.84 \pm 0.27$ \\
& $\mathrm{D}$ & $48.86 \pm 2.74 \mathrm{a}$ & $18.56 \pm 0.64 \mathrm{a}$ & $6.40 \pm 0.39 \mathrm{~b}$ & $1.73 \pm 0.33 \mathrm{a}$ & $17.38 \pm 1.55$ & $2.49 \pm 0.45$ \\
\hline \multirow{2}{*}{$\mathrm{Cy}$} & $\mathrm{F}$ & $40.71 \pm 1.27 \mathrm{a}$ & $22.25 \pm 1.52 \mathrm{~b}$ & $4.00 \pm 0.64 \mathrm{a}$ & $2.83 \pm 0.23 \mathrm{a}$ & $24.36 \pm 3.16$ & $4.85 \pm 0.53$ \\
& $\mathrm{D}$ & $46.19 \pm 1.51 \mathrm{~b}$ & $17.97 \pm 1.73 \mathrm{a}$ & $5.27 \pm 0.90 \mathrm{~b}$ & $2.56 \pm 0.22 \mathrm{a}$ & $16.93 \pm 0.88$ & $3.65 \pm 0.66$ \\
\hline \multirow{2}{*}{$\mathrm{Ec}$} & $\mathrm{F}$ & $47.86 \pm 2.46 \mathrm{a}$ & $19.65 \pm 1.83 \mathrm{a}$ & $4.11 \pm 0.35 \mathrm{a}$ & $4.10 \pm 0.12 \mathrm{a}$ & $25.85 \pm 0.60$ & $6.62 \pm 0.42$ \\
& $\mathrm{D}$ & $45.53 \pm 5.10 \mathrm{a}$ & $21.96 \pm 1.44 \mathrm{a}$ & $5.86 \pm 0.55 \mathrm{~b}$ & $3.91 \pm 0.27 \mathrm{a}$ & $17.04 \pm 3.14$ & $4.15 \pm 0.13$ \\
\hline \multirow{2}{*}{$\mathrm{Ca}+\mathrm{Ci}$} & $\mathrm{F}$ & $41.90 \pm 2.31 \mathrm{a}$ & $18.94 \pm 1.94 \mathrm{a}$ & $4.52 \pm 0.25 \mathrm{a}$ & $1.42 \pm 0.13 \mathrm{a}$ & $18.87 \pm 0.79$ & $5.59 \pm 0.43$ \\
& $\mathrm{D}$ & $45.99 \pm 1.46 \mathrm{a}$ & $22.30 \pm 3.69 \mathrm{a}$ & $5.38 \pm 0.16 \mathrm{~b}$ & $1.62 \pm 0.12 \mathrm{a}$ & $15.44 \pm 1.26$ & $3.57 \pm 0.66$ \\
\hline \multirow{2}{*}{$\mathrm{Eu}+\mathrm{Er}$} & $\mathrm{F}$ & $41.24 \pm 0.77 \mathrm{a}$ & $24.08 \pm 1.14 \mathrm{~b}$ & $4.70 \pm 0.04 \mathrm{a}$ & $3.26 \pm 0.05 \mathrm{a}$ & $28.67 \pm 6.11$ & $11.83 \pm 1.61$ \\
& $\mathrm{D}$ & $48.90 \pm 1.55 \mathrm{~b}$ & $17.53 \pm 1.35 \mathrm{a}$ & $5.70 \pm 0.42 \mathrm{~b}$ & $3.60 \pm 0.37 \mathrm{a}$ & $14.83 \pm 0.32$ & $4.43 \pm 0.14$ \\
\hline \multirow{2}{*}{$\mathrm{Er}$} & $\mathrm{F}$ & $43.10 \pm 2.37 \mathrm{a}$ & $23.83 \pm 1.94 \mathrm{~b}$ & $3.41 \pm 0.38 \mathrm{a}$ & $1.11 \pm 0.12 \mathrm{a}$ & $43.97 \pm 1.03$ & $6.36 \pm 1.43$ \\
& $\mathrm{D}$ & $50.93 \pm 2.48 \mathrm{~b}$ & $17.97 \pm 1.73 \mathrm{a}$ & $5.30 \pm 0.71 \mathrm{~b}$ & $1.34 \pm 0.11 \mathrm{a}$ & $29.90 \pm 3.24$ & $2.55 \pm 0.04$ \\
\hline
\end{tabular}

Note. Sample codification explained in Table 1; F - frozen, D - dried; TPC - total phenolic content, TFC - total flavonoid content; $\mathrm{GAE}$ - gallic acid equivalent, $\mathrm{CAE}$ - catechin equivalent.

Table 4. Component variance analysis for the fatty acids content in pollen from different species and two storage methods (variance percentage significance level)

\begin{tabular}{lcccc}
\hline & \multicolumn{4}{c}{ Variance source } \\
\cline { 2 - 5 } & $\begin{array}{c}\text { species } \\
(\mathrm{S})\end{array}$ & $\begin{array}{c}\text { storage } \\
\text { method (F) }\end{array}$ & $\mathrm{S} \times \mathrm{F}$ & residual \\
\hline Acidity (pH) & $21.5^{*}$ & $0.0 \mathrm{~ns}$ & $0.0 \mathrm{~ns}$ & 78.5 \\
Total acidity, meq & $73.2^{* * *}$ & $0.0 \mathrm{~ns}$ & $0.0 \mathrm{~ns}$ & 26.8 \\
NaOH kg & & & & \\
Fibre \% & $95.1^{* * *}$ & $0.0 \mathrm{~ns}$ & $0.0 \mathrm{~ns}$ & 4.9 \\
Ash \% & $35.2^{* * *}$ & $0.0 \mathrm{~ns}$ & $35.3^{* * *}$ & 29.5 \\
Reducing sugar \% & $9.6^{* *}$ & $30.4^{* * *}$ & $35.6^{* * *}$ & 24.4 \\
Protein \% & $9.8^{* *}$ & $5.0^{*}$ & $57.7^{* * *}$ & 27.5 \\
Lipids \% & $20.1^{* * *}$ & $61.4^{* * *}$ & $0.0 \mathrm{~ns}$ & 18.5 \\
TPC mg GAE g ${ }^{-1}$ & $50.7^{* * *}$ & $37.2^{* * *}$ & $4.6^{*}$ & 7.5 \\
TFC mg CAE g ${ }^{-1}$ & $36.9^{* * *}$ & $22.4^{* * *}$ & $35.5^{* * *}$ & 5.3 \\
\hline
\end{tabular}

Note. TPC - total phenolic content, TFC - total flavonoid content; GAE - gallic acid equivalent, CAE - catechin equivalent; residual is the variance that is not explained by any of the considered factor and represent also the variability observed in the sample studied; ns - not significant $(P>0.05)$; $*$ - significant $(0.01<P<0.05), * *$ - very significant $(0.001<$ $P<0.01),{ }^{* * *}$ - highly significant $(P<0.001)$.

The acidity of bee pollen ranged from 13.5 to 21.2 meq $\mathrm{NaOH} \mathrm{kg}{ }^{-1}$ (Table 2) and the variability observed may be mainly attributed to the different species, which explains $73.2 \%$ of the total variance (Table4). Regarding the ash content, the effect of the storage method was not significant. Indeed, the main variance of this parameter was due to the different plant species, which explains $35.2 \%$ of the total variance. The mean values found for ash content are similar to those reported in the literature (Feás et al., 2012; Anjos et al., 2017), and the samples with higher ash content are obtained from Castanea sativa, Cistus spp., Eucalyptus spp. and Erica spp. (Table 2).
The nutritional value of bee pollen varies considerably between the plant species and is also highly influenced by the storage method (Table 4). Indeed, according to the literature, the variability of nutrient content of bee pollen is usually attributed to differences in the climatic conditions, different provenances and soil (Campos et al., 2016). It may also be influenced by the apicultural practices. The variance of reducing sugars between species is very significant and explains $9.6 \%$ of variance, as well as the storage method is highly significant and explains $30.4 \%$ of the total variance (Table 4). However, the interaction between storage method and species explains only $35.6 \%$ of the total variation, meaning that drying increases the reducing sugar content, but some additional factors influence the decrease of sugar concentrations. It has been reported that an increase in temperature as well as a variation in acidity $(\mathrm{pH})$ promotes the interactions between the sugars and the amino groups of protein (Martins et al., 2000). This at least partly explains the variation observed in our study, though the drying process does not exceed $40^{\circ} \mathrm{C}$. Further studies are needed to better understand this behaviour.

The mean values observed for reducing sugar content of bee pollen are similar to those reported by Anjos et al. (2017) and Gonçalves et al. (2017).

The average protein content of bee pollen samples ranged from $17.52 \%$ for bee pollen of Rubus spp. to $24.53 \%$ for bee pollen of Cistus spp. The large variation among pollen from different plants was also observed by other authors (Feás et al., 2012). The variation in the protein content in the different species is very significant, but explains only $10 \%$ of the total variability. The storage method explains $5 \%$, while the interaction among the two factors explains $58 \%$ of the total variance and that is due to different pattern of behaviour of the different species when applying freezing. In many cases it was observed that the protein content is higher in the frozen bee pollen samples. Proteins are complex molecules composed of long chains of amino acids. These molecules have 
a three-dimensional shape that can be easily denatured by different factors, such as temperature, acidity $(\mathrm{pH})$, salts, etc. Denaturation causes the structural changes in the protein and even though nutritional value remains the same, their biological activity is affected and this results in the different value of protein (Korhonen et al., 1998).

Pollen lipids are very important for honeybee's nutrition and play a relevant role in their development, nutrition and reproduction (Szczęsna et al., 2002). Lipids comprise some important molecules for human nutrition as well among which essential fatty acids and some antioxidant compounds are of extreme importance (Mărgăoan et al., 2014; Arien et al., 2015).

The lipid fraction of bee pollen, like other constituents, varies significantly among the different botanical species (Szczęsna, 2006; Yang et al., 2013). In this study it was observed that the effect of the different species is highly significant and explains $20.1 \%$ of the total variation observed, corroborating previously published findings. It was found that the storage period is also highly significant and explains $61.4 \%$ of the total variation.

The values obtained for lipids were significantly higher in dried bee pollen. This could be explained by two different processes: (1) possible structural changes induced by thermal processing, among which the uncatalysed hydrolysis, and (2) thermic induced changes on enzymatic activity (Salimon et al., 2011). The temperature used in bee pollen drying process is near the optimum temperature for lipase activation $\left(40^{\circ} \mathrm{C}\right)$, therefore these conditions promote the enzymatic hydrolysis of lipids to fatty acids (Wanyo et al., 2014). Komosinska-Vassev et al. (2015) reported the presence of lipase from the salivary glands of the honeybee, especially the labial ones, in bee pollen. Our results are in agreement with those reported by Telahigue et al. (2013), where it was stated that drying causes significant increase of saturated fatty acids (SFA) and monounsaturated fatty acids (MUFA).

The effect of the storage method on the fibre content is not significant and the main variance of this factor is related to the plant species, which explains
$95.1 \%$ of the variance regarding the fibre content and $35.2 \%$ for the ash content (Table 4 ).

The highest ash values were observed in the samples of Echium spp. and Eucalyptus spp. + Erica spp., and the lowest values in the samples of Erica spp. and Cistus spp. The average values of fibre content of dried bee pollen found in this work are similar to those reported by Anjos et al. (2017).

Polyphenols namely, phenolic acids and flavonoids are key bee pollen compounds in the bee pollen that have been reported to be powerful antioxidants and the most essential non-nutrient components (Rice-Evans et al., 1996). Bee pollen is rich in polyphenols, which determines its biological activity (Leja et al., 2007; Gonçalves et al., 2017). Several studies in pure or mixed pollen have reported an important antioxidant activity related to the polyphenols, such as flavones, flavonols, isoflavones, flavonones, anthocyanins, catechin and isocatechin (Almaraz-Abarca et al., 2007; Morais et al., 2011).

For total phenolic and total flavonoid contents the factors "species" and "storage method" are highly significant (Table 4). In both cases the average values for frozen bee pollen are higher than those observed for the dried samples. These differences are higher for some species, which explains the percentage of variance observed in the ANOVA interaction. The average values of total phenolic and total flavonoid contents in dried bee pollen are similar to those reported in the literature. According to the Abhay et al. (2016), drying process promotes the degradation of polyphenols via both enzymatic and non-enzymatic oxidation of phenolic compounds leading to the browning of the product. According to other authors, polyphenol-oxidase enzymes are activated during drying.

The assessment of the microbiological quality of bee pollen is essential to ensure its safety for human consumption. In this work we studied both quality (count of aerobic mesophilic and moulds and yeasts) and safety parameters (Bacillus cereus, sulphite-reducing clostridia spores, Staphylococcus aureus, Salmonella spp. and Listeria monocytogenes) (Table 5). The aerobic

Table 5. Microbiological analysis of the quality of bee pollen

\begin{tabular}{|c|c|c|c|c|}
\hline \multirow{2}{*}{ Code } & \multirow{2}{*}{$\begin{array}{l}\text { Storage } \\
\text { method }\end{array}$} & Mesophilic bacteria & Moulds and yeasts & Bacillus cereus \\
\hline & & \multicolumn{3}{|c|}{$\mathrm{CFU} \mathrm{g}^{-1}$} \\
\hline \multirow{2}{*}{$\mathrm{Ru}$} & $\mathrm{F}$ & $2.76 \times 10^{2} \pm 6.69 \times 10^{1}$ & $6.33 \times 10^{2} \pm 1.37 \times 10^{2}$ & $<10$ \\
\hline & $\mathrm{D}$ & $1.39 \times 10^{3} \pm 2.14 \times 10^{1}$ & $2.08 \times 10^{2} \pm 9.41 \times 10^{1}$ & $<10$ \\
\hline \multirow{2}{*}{$\mathrm{Ca}$} & $\mathrm{F}$ & $1.84 \times 10^{2} \pm 3.21 \times 10^{1}$ & $1.51 \times 10^{3} \pm 1.78 \times 10^{2}$ & $1.47 \times 10^{2} \pm 2.11 \times 10^{1}$ \\
\hline & $\mathrm{D}$ & $5.55 \times 10^{2} \pm 4.09 \times 10^{1}$ & $9.53 \times 10^{1} \pm 2.70 \times 10^{1}$ & $2.70 \times 10^{2} \pm 3.78 \times 10^{1}$ \\
\hline \multirow{2}{*}{$\mathrm{Ci}$} & $\mathrm{F}$ & $1.09 \times 10^{2} \pm 3.49 \times 10^{1}$ & $5.85 \times 10^{2} \pm 6.10 \times 10^{1}$ & $<10$ \\
\hline & $\mathrm{D}$ & $3.57 \times 10^{1} \pm 5.10 \times 10^{0}$ & $5.17 \times 10^{1} \pm 1.04 \times 10^{1}$ & $<10$ \\
\hline \multirow{2}{*}{ Le } & $\mathrm{F}$ & $2.72 \times 10^{2} \pm 1.15 \times 10^{2}$ & $6.38 \times 10^{2} \pm 1.33 \times 10^{2}$ & $4.63 \times 10^{2} \pm 4.55 \times 10^{1}$ \\
\hline & $\mathrm{D}$ & $8.97 \times 10^{1} \pm 8.50 \times 10^{0}$ & $1.44 \times 10^{2} \pm 2.82 \times 10^{1}$ & $6.26 \times 10^{2} \pm 3.88 \times 10^{1}$ \\
\hline \multirow{2}{*}{ Cy } & $\mathrm{F}$ & $2.67 \times 10^{2} \pm 1.46 \times 10^{1}$ & $6.52 \times 10^{2} \pm 7.26 \times 10^{1}$ & $<10$ \\
\hline & $\mathrm{D}$ & $1.42 \times 10^{2} \pm 3.87 \times 10^{1}$ & $8.47 \times 10^{1} \pm 1.17 \times 10^{1}$ & $<10$ \\
\hline \multirow{2}{*}{ Ec } & $\mathrm{F}$ & $2.03 \times 10^{2} \pm 4.39 \times 10^{1}$ & $1.73 \times 10^{3} \pm 7.31 \times 10^{1}$ & $2.06 \times 10^{2} \pm 2.91 \times 10^{1}$ \\
\hline & $\mathrm{D}$ & $1.01 \times 10^{3} \pm 2.68 \times 10^{1}$ & $2.01 \times 10^{2} \pm 2.54 \times 10^{1}$ & $2.17 \times 10^{2} \pm 9.07 \times 10^{0}$ \\
\hline \multirow{2}{*}{$\mathrm{Ca}+\mathrm{Ci}$} & $\mathrm{F}$ & $2.64 \times 10^{2} \pm 6.50 \times 10^{1}$ & $7.25 \times 10^{2} \pm 1.13 \times 10^{2}$ & $<10$ \\
\hline & $\mathrm{D}$ & $7.77 \times 10^{1} \pm 1.17 \times 10^{1}$ & $1.59 \times 10^{2} \pm 1.55 \times 10^{1}$ & $<10$ \\
\hline \multirow{2}{*}{$\mathrm{Eu}+\mathrm{Er}$} & $\mathrm{F}$ & $1.95 \times 10^{2} \pm 2.59 \times 10^{1}$ & $2.96 \times 10^{2} \pm 1.17 \times 10^{1}$ & $<10$ \\
\hline & $\mathrm{D}$ & $2.87 \times 10^{1} \pm 6.10 \times 10^{0}$ & $1.83 \times 10^{1} \pm 1.50 \times 10^{0}$ & $<10$ \\
\hline \multirow{2}{*}{$\mathrm{Er}$} & $\mathrm{F}$ & $1.23 \times 10^{3} \pm 3.75 \times 10^{1}$ & $7.57 \times 10^{2} \pm 7.12 \times 10^{1}$ & $4.24 \times 10^{2} \pm 2.65 \times 10^{1}$ \\
\hline & $\mathrm{D}$ & $8.47 \times 10^{1} \pm 1.34 \times 10^{1}$ & $1.82 \times 10^{2} \pm 2.10 \times 10^{1}$ & $4.00 \times 10^{2} \pm 1.88 \times 10^{1}$ \\
\hline
\end{tabular}

Note. Sample codification explained in Table 1; F - frozen, D - dried; CFU - colony forming units. 
mesophilic microorganism counts ranged from $3.57 \times$ $10^{1}$ to $1.39 \times 10^{3}$ colony-forming unit $(\mathrm{CFU}) \mathrm{g}^{-1}$, while B. cereus counts ranged from $<10$ to $6.26 \times 10^{2} \mathrm{CFU} \mathrm{g}^{-1}$. The counts for moulds and yeasts were found to be in the following sequence: $\mathrm{Er}>\mathrm{Ru}>\mathrm{Ec}>\mathrm{Ca}>\mathrm{Ca}+\mathrm{Ci}$ $>\mathrm{Cy}>\mathrm{Le}>\mathrm{Ci}>\mathrm{Eu}+$ Er. As it is shown in Table 5, yeasts and moulds were detected in significantly higher amounts in the frozen bee pollen when compared to the dried samples.

Microbiological quality of bee pollen varied depending on the conservation method, geographical origin of the sample and the type (even amongst the samples collected in the same location). This may be related to the hygiene practices during harvesting and processing, but also to the microbiota available on the plant material and bee pollen from the different botanical and geographical areas (Mauriello et al., 2017). Total coliforms, Escherichia coli, sulphite-reducing clostridium spores, Salmonella spp. and Listeria monocytogenes, which are very important pathogenic microorganisms, were absent in all the analysed samples. Even though studies on the microbiological quality of bee pollen, particularly regarding the frozen products, are scanty, still hereby reported results are in agreement with those presented in the literature. In particular, Estevinho et al. (2012) and Feás et al. (2012) who studied Portuguese bee pollen, De-Melo et al. (2016) who assessed Brazilian pollen, and Mauriello et al. (2017) who evaluated Italian pollen. Our results are also in line with those recommended by the International Honey Commission (Campos et al., 2008).

Different nutritional composition was obtained for the sub-groups (dried or frozen). This influence is presented in Figure, which represent the projection of the pollen samples on the plane of the two main factors resulting from principal component analysis (PCA) for all chemical analysis. The PCA explains $64.3 \%$ of the total variance observed.

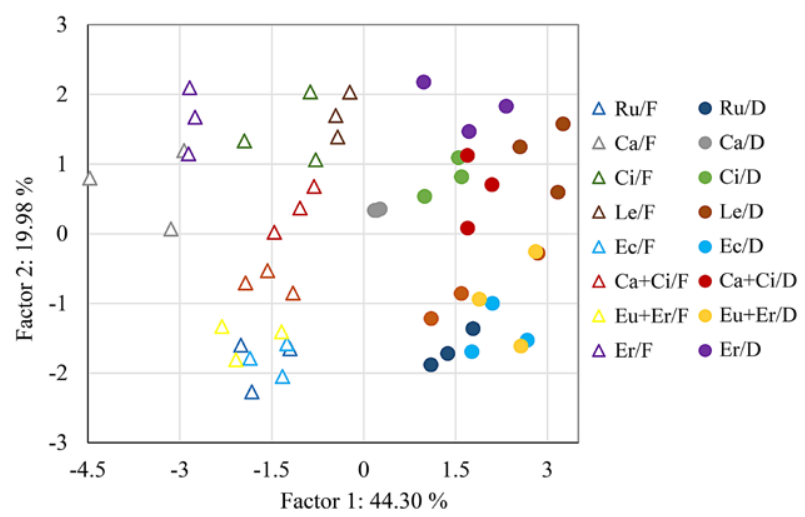

Note. Sample codification explained in Table 1; F - frozen, $\mathrm{D}$ - dried.

Figure. Projection of the pollen samples on the plane of the two more representative factors resulting from principal component analysis

\section{Conclusion}

In this study it was shown that the storage method influences the nutritional composition of bee pollen samples. The concentration of reducing sugars, lipids, total phenolic content and total flavonoid content were highly influenced by the storage method, which also had impact on the significant differences in protein content. These differences were substantial even considering the variability attributed to the botanical origin of bee pollen. The total phenolic and flavonoid contents were higher than those of the frozen bee pollen, which might have beneficial effect on health. On the other hand, frozen bee pollen had higher water activity and a higher amount of yeasts and moulds, which implies that the freezing must be done very carefully in order to prevent microbial spoilage. The conclusion, based on the parameters evaluated in this study, can be drawn that frozen bee pollen is more useful than dried one regarding the nutritional value. However, due to the lower microbiological contamination the dried bee pollen is a safer option to use in the human diet.

\section{Acknowledgements}

Centro de Estudos Florestais is a research unit funded by Fundação para a Ciência e Tecnologia, (UID/ AGR/00239/2019).

Received 13042018

Accepted 05102018

\section{References}

1. Abhay S. M., Hii C. L., Law C. L., Suzannah S., Djaeni M. 2016. Effect of hot-air drying temperature on the polyphenol content and the sensory properties of cocoa beans. International Food Research Journal, 23 (4): 1479-1484.

2. Almaraz-Abarca N., Campos M., Ávila-Reyes J. A., Naranjo-Jiménez N., Corral J. H., González-Valdez L. S. 2007. Antioxidant activity of polyphenolic extract of monofloral honeybee-collected pollen from mesquite (Prosopis juliflora, Leguminosae). Journal of Food Composition and Analysis, 20 (2): 119-124. https://doi.org/10.1016/j.jfca.2006.08.001

3. Anjos O., Santos A. J. A., Dias T., Estevinho L. M. 2017. Application of FTIR-ATR spectroscopy on the bee pollen characterization. Journal of Apicultural Research, 56 (3): 210-218. https://doi.org/10.1080/00218839.2017.1289657

4. AOAC. 1995. Official methods of analysis $\left(16^{\text {th }} \mathrm{ed}\right.$. $)$.

5. AOAC. 2000 . Official methods of analysis $\left(17^{\text {th }} \mathrm{ed}\right.$.).

6. AOAC. 2002. Official methods of analysis ( $16^{\text {th }} \mathrm{ed}$.).

7. Arien Y., Dag A., Zarchin S., Masci T., Shafir S. 2015. Omega-3 deficiency impairs honey bee learning. Phychological and Cognitive Sciences, 112 (51): 15761-15766. https://doi.org/10.1073/pnas.1517375112

8. Arruda S. V. A., Pereira A. A. S., Estevinho L. M., de Almeida-Muradian L. B. 2013. Presence and stability of B complex vitamins in bee pollen using different storage conditions. Food and Chemical Toxicology, 51: 143-148. https://doi.org/10.1016/j.fct.2012.09.019

9. Barth O. M., Freitas A. S., Oliveira E. S., Silva R. A., Maester F. M., Andrella R. R. S., Cardozo G. M. B. Q. 2010. Evaluation of the botanical origin of commercial dry bee pollen load batches using pollen analysis: a proposal for technical standardization. Anais da Academia Brasileira de Ciências, 82 (4): 893-902. https://doi.org/10.1590/S0001-37652010000400011

10. Bonvehi J. S., Jordà R. E. 1997. Nutrient composition and microbiological quality of honeybee-collected pollen in Spain. Journal of Agriculture and Food Chemistry, 45 (3): 725-732.

https://doi.org/10.1021/jf960265q 
11. Campos M. G. R., Bogdanov S., de Almeida-Muradian L. B., Szczęsna T., Mancebo Y., Frigerio C., Ferreira F. 2008. Pollen composition and standardisation of analytical methods. Journal of Apicultural Research, 47 (2): 154-161. https://doi.org/10.1080/00218839.2008.11101443

12. Campos M. G., Olena L., Anjos O. 2016. Chemical composition of bee pollen. Cardoso S. M. et al. (eds). Chemistry, biology and potential applications of honeybee plant-derived products. Bentham eBooks, p. 67-88. https://doi.org/10.2174/9781681082370116010006

13. Carpes S. T., Mourão G. B., de Alencar S. M., Masson M. L. 2009. Chemical composition and free radical scavenging activity of Apis mellifera bee pollen from Southern Brazil. Brazilian Journal of Food Technology, 12 (3): 220-229. https://doi.org/10.4260/BJFT2009800900016

14. Cornara L., Biagi M., Xiao J., Burlando B. 2017. Therapeutic properties of bioactive compounds from different honeybee products. Frontiers in Pharmacology, 8: 412. https://doi.org/10.3389/fphar.2017.00412

15. De-Melo A. A. M., Estevinho M. L. M. F., Sattler J. A. G., Souza B. R., Freitas A. da S., Barth O. M., AlmeidaMuradian L. B. 2016. Effect of processing conditions on characteristics of dehydrated bee-pollen and correlation between quality parameters. LWT - Food Science and Technology, 65: 808-815.

https://doi.org/10.1016/j.1wt.2015.09.014

16. Estevinho L. M., Rodrigues S., Pereira A. P., Feás X. 2012. Portuguese bee pollen: palynological study, nutritional and microbiological evaluation. International Journal of Food Science and Technology, 47 (2): 429-435. https://doi.org/10.1111/j.1365-2621.2011.02859.x

17. Feás X., Vázquez-Tato M. P., Estevinho L. M., Seijas J. A., Iglésias A. 2012. Organic bee pollen: botanical origin, nutritional value, bioactive compounds, antioxidant activity and microbiological quality. Molecules, 17 (7): 8359-8377. https://doi.org/10.3390/molecules17078359

18. Gonçalves J. S. P., Estevinho M. L., Pereira A. P., Sousa J. M. C., Anjos O. 2017. Computational intelligence applied to discriminate bee pollen quality and botanical origin. Food Chemistry, 267: 36-42.

https://doi.org/10.1016/j.foodchem.2017.06.014

19. Human H., Nicolson S. W. 2006. Nutritional content of fresh, bee-collected and stored pollen of Aloe greatheadii var. davyana (Asphodelaceae). Phytochemistry, 67: 1486-1492.

https://doi.org/10.1016/j.phytochem.2006.05.023

20. Komosinska-Vassev K., Olczyk P., Kafmierczak J., Mencner L., Olczyk K. 2015. Bee pollen: chemical composition and therapeutic application: review article. Evidence-Based Complementary and Alternative Medicine, 2015: ID 297425.

21. Korhonen H., Pihlanto-Leppäla A., Rantamäki P., Tupasela T. 1998. Impact of processing on bioactive proteins and peptides. Trends in Food Science and Technology, 9 (8-9): 307-319. https://doi.org/10.1016/S0924-2244(98)00054-5

22. Leja M., Mareczek A., Wyzgolik G., Klepacz-Baniak J., Czekonska K. 2007. Antioxidative properties of bee pollen in selected plant species. Food Chemistry, 100 (1): 237-240.

https://doi.org/10.1016/j.foodchem.2005.09.047

23. Mărgăoan R., Mărghitas L. A., Dezmirean D. S., Dulf F. V., Bunea A., Socaci S. A., Bobiş O. 2014. Predominant and secondary pollen botanical origins influence the carotenoid and fatty acid profile in fresh honeybee-collected pollen. Journal of Agriculture and Food Chemistry, 62 (27): 6306-6316. https://doi.org/10.1021/jf5020318
24. Martins S. I. F. S., Jongen W. M. F., van Boekel M. A. J. S. 2000. A review of Maillard reaction in food and implications to kinetic modelling. Trends in Food Science and Technology, 11 (9-10): 364-373.

https://doi.org/10.1016/S0924-2244(01)00022-X

25. Mauriello G., De Prisco A., Di Prisco G., La Storia A., Caprio E. 2017. Microbial characterization of bee pollen from the Vesuvius area collected by using three different traps. PLoS ONE, 12 (9): e0183208.

https://doi.org/10.1371/journal.pone.0183208

26. Morais M., Moreira L., Feás X., Estevinho L. M. 2011. Honeybee-collected pollen from five Portuguese Natural Parks: palynological origin, phenolic content, antioxidant properties and antimicrobial activity. Food and Chemical Toxicology, 49 (5): 1096-1101. https://doi.org/10.1016/j.fct.2011.01.020

27. Moreira L., Dias L. G., Pereira J. A., Estevinho L. 2008. Antioxidant properties, total phenols and pollen analysis of propolis samples from Portugal. Food and Chemical Toxicology, 46 (11): 3482-3485. https://doi.org/10.1016/j.fct.2008.08.025

28. Rice-Evans C. A., Miller N. J., Paganga G. 1996. Structure-antioxidant activity relationships of flavonoids and phenolic acids. Free Radical Biology and Medicine, 20 (7): 933-956.

https://doi.org/10.1016/0891-5849(95)02227-9

29. Sagona S., Pozzo L., Peiretti P. G., Biondi C., Giusti M., Gabriele M., Pucci L., Felicioli A. 2017. Palynological origin, chemical composition, lipid peroxidation and fatty acid profile of organic Tuscanian bee-pollen. Journal of Apicultural Research, 56 (2): 136-143. https://doi.org/10.1080/00218839.2017.1287995

30. Salimon J., Abdullah B. M., Salih N. 2011. Hydrolysis optimization and characterization study of preparing fatty acids from Jatropha curcas seed oil. Chemistry Central Journal, 5 (67): 1-9. https://doi.org/10.1186/1752-153X-5-67

31. Siuda M., Wilde J., Bak T. 2012. The effect of various storage methods on organoleptic quality of bee pollen loads. Journal of Apicultural Science, 56 (1): 71-79. https://doi.org/10.2478/v10289-012-0008-8

32. Szczęsna T. 2006. Long-chain fatty acids composition of honeybee-collected pollen. Journal of Apicultural Science, 50 (2): 65-79.

33. Szczęsna T., Rybak-Chielewska H., Chmielewski W. 2002. Sugar composition of pollen loads harvested at different periods of the beekeeping season. Journal of Apicultural Science, 46 (2): 107-115.

34. Telahigue K., Hajji T., Rabeh I., Cafsi M. E. 2013. The changes of fatty acid composition in sun dried, oven dried and frozen hake (Merluccius merluccius) and sardinella (Sardinella aurita). African Journal of Biochemistry Research, 7 (8): 158-164.

35. Wanyo P., Meeso N., Siriamornpun S. 2014. Effects of different treatments on the antioxidant properties and phenolic compounds of rice bran and rice husk. Food Chemistry, 157: 457-463. https://doi.org/10.1016/j.foodchem.2014.02.061

36. Yang K., Wu D., Ye X., Lui D., Chen J., Sun P. 2013. Characterization of chemical composition of bee pollen in China. Journal of Agricultural and Food Chemistry, 61 (3): 708-718. https://doi.org/10.1021/jf304056b 
ISSN 1392-3196 / e-ISSN 2335-8947

Zemdirbyste-Agriculture, vol. 106, No. 1 (2019), p. 87-94

DOI $10.13080 /$ z-a.2019.106.012

\title{
Laikymo sąlygų įtaka bičių surinktų žiedadulkių kokybei
}

\author{
O. Anjos ${ }^{1,2,3}$, V. Paula ${ }^{4}$, T. Delgado 2 L. Estevinho ${ }^{5}$ \\ ${ }^{1}$ Lisabonos universiteto Agronomijos instituto Miškų studijų centras, Portugalija \\ ${ }^{2}$ Castelo Branco politechnikos institutas, Portugalija \\ ${ }^{3}$ Beira augalų biotechnologijų centras, Portugalija \\ ${ }^{4}$ Bragança politechnikos instituto Žemès ūkio mokykla, Portugalija \\ ${ }^{5}$ Bragança politechnikos instituto Kalnų tyrimų centras, Portugalija
}

\section{Santrauka}

Bičių surinktos žiedadulkès yra sveikas maisto produktas, pasižymintis didele mitybine verte ir terapinėmis savybėmis. Tačiau ilgas laikymas gali paveikti žiedadulkių sudètị ir savybes. Tyrimo metu siekta ịvertinti laikymo sąlygų įtaką bičių surinktų ịvairių monoflorinių žiedadulkių mėginių cheminei sudéčiai: rūgštumui (pH), vandens aktyvumui, suminiam rūgštumui ir ląstelienos, pelenų, redukuojančių cukrų, baltymų, lipidų, suminiams fenolių bei flavonoidų kiekiams. Bičių surinktų žiedadulkių devyni mėginiai buvo paimti trijose Šiaurès Rytų Portugalijos vietovèse ir padalinti ị du bandinius: vienas užšaldytas $-20^{\circ} \mathrm{C}$ temperatūroje, kitas džiovintas $42^{\circ} \mathrm{C}$ temperatūroje iki 6-8 \% drègnio. Nors botaninès kilmès skirtumai yra svarbus veiksnys, paaiškinantis variaciją tarp mėginių, nustatyta, kad laikymo būdas yra labai svarbus veiksnys keliems parametrams: redukuojančių cukrų, lipidų, suminiams fenolių ir flavonoidų kiekiams. Didesni kiekiai aerobinių mezofilų, pelèsių ir mielių buvo nustatyti užšaldytose žiedadulkèse, tačiau visuose mėginiuose ir taikant abu žiedadulkių laikymo būdus jų kiekiai buvo mažesni nei nurodyta standartuose.

Tyrimo duomenys rodo, kad geriau vartoti $-20^{\circ} \mathrm{C}$ temperatūroje užšaldytas bičių surinktas žiedadulkes nei džiovintas elektrinèje krosnelëje.

Reikšminiai žodžiai: džiovintos žiedadulkès, fizikocheminè analizè, mikrobiologinè analizè, šaldytos žiedadulkès. 